\title{
OCHRONA WIĘZI PRAWNORODZINNYCH PRZEPISAMI O OCHRONIE DÓBR OSOBISTYCH. ZADOŚĆUCZYNIENIE ZA NIEWY PEŁNIENIE OBOWIĄZKÓW MAŁŻEŃSKICH. GLOSA DO WYROKU SĄDU NAJWYŻSZEGO Z 11 GRUDNIA 2018 ROKU (IV CNP 31/17) ${ }^{1}$
}

\begin{abstract}
Abstrakt: Zagadnienie dóbr osobistych i ich ochrony prawnej podlega ciągłej aktualizacji. Glosa do wyroku Sądu Najwyższego z dnia 11 grudnia 2018 roku wskazuje na problematykę rozwoju orzecznictwa dotyczącego dóbr osobistych na przykładzie tak zwanej zdrady małżeńskiej, odnośnie do której do ochrony więzi prawnorodzinnych między małżonkami nie mają zastosowania przepisy o ochronie dóbr osobistych. Autor aprobuje wyrok Sądu Najwyższego, rozszerzając jego argumentację, oraz wskazuje na zagadnienia prawne, jakie mogą się pojawić w związku z interpretacją wyroku.

Słowa kluczowe: więzi prawnorodzinne, naruszenie obowiązków małżeńskich, zadośćuczynienie, naprawienie krzywdy, zdrada małżeńska, wierność małżeńska
\end{abstract}

\section{TEZA}

W wypadku tak zwanej zdrady małżeńskiej do ochrony więzi prawnorodzinnych między małżonkami nie mają zastosowania przepisy o ochronie dóbr osobistych.

\section{WSTĘP}

Wyrok Sądu Najwyższego z dnia 11 grudnia 2018 roku traktuje o istotnych kwestiach związanych z możliwością dochodzenia roszczeń wynikających z obowiązków małżeńskich na podstawie przepisów kodeksu cywilnego o ochronie dóbr osobistych ${ }^{2}$. Zagadnienia prawne, do jakich nawiązuje orzeczenie, są złożo-

1 Wyrok Sądu Najwyższego z dnia 11 grudnia 2018 r., IV CNP 31/17, LEX nr 2621125.

2 Ustawa z dnia 23 kwietnia 1964 roku Kodeks cywilny, tekst jedn. Dz.U. z 2019 r. poz. 1145 ze zm. 
ne i dotyczą między innymi dynamicznego rozwoju orzecznictwa w przedmiocie ochrony dóbr osobistych, problematyki ustalania przez sąd przesłanek naruszenia dobra osobistego czy zakresu stosowania art. $446 \S 4$ oraz 448 w zw. z art. 24 k.c.

Glosowany wyrok został wydany na skutek skargi Rzecznika Praw Obywatelskich o stwierdzenie niezgodności z prawem prawomocnego orzeczenia zasądzającego zadośćuczynienie pieniężne za doznaną krzywdę w związku z naruszeniem dóbr osobistych.

Sąd Najwyższy słusznie uznał wyrok sądu okręgowego za niezgodny z prawem, jednak przytoczona argumentacja nie uzasadnia w pełni tezy orzeczenia. Wobec stosunkowo nieoczywistego oraz kontrowersyjnego, z punktu widzenia norm obyczajowych, stanu faktycznego, należałoby poszerzyć dowodzenie oraz wskazać na wątpliwości, jakie mogą się pojawić w związku z interpretacją przedmiotowego wyroku.

\section{STAN FAKTYCZNY}

Powód wniósł o zasądzenie od byłej żony oraz jej obecnego męża kwoty tytułem zadośćuczynienia na podstawie art. $24 \mathrm{w}$ zw. z art. 448 k.c. podnosząc, że po niespełna trzynastu latach małżeństwa dowiedział się o niewierności żony oraz że każde z czworga urodzonych przez nią dzieci jest owocem pozamałżeńskiej relacji żony z kolegą powoda. Fakt ten miał być przyczyną załamania psychicznego powoda. W jego odczuciu żona go ośmieszyła, ukrywając wieloletni romans oraz faktyczne pochodzenie dzieci, które przyszły na świat w czasie trwania ich małżeństwa. Mężczyzna wstydził się wyjść z domu, twierdząc, że zachowanie żony spowodowało jego negatywną ocenę ze strony lokalnego środowiska. Sąd pierwszej instancji doszedł do przekonania, że niemoralne zachowanie pozwanej naruszyło między innymi dobro osobiste w postaci poczucia istnienia więzi rodzinnych z żoną i dziećmi, w związku z tym uwzględnił powództwo, zasądzając na rzecz powoda kwotę tytułem zadośćuczynienia pieniężnego za doznaną krzywdę.

\section{WIĘZI RODZINNE JAKO DOBRO OSOBISTE}

\subsection{PRZESŁANKI OCHRONY WYPRACOWANE PRZEZ ORZECZNICTWO}

Celem uzupełnienia oraz skorygowania rozważań poczynionych $\mathrm{w}$ orzeczeniu SN należy początkowo odwołać się do znaczenia więzi rodzinnych jako dobra osobistego. Orzecznictwo sądów, jak przyznaje SN, wykształciło dobro osobiste, którego istota sprowadza się do więzi łączących osoby bliskie i najczęściej jest ono ujmowane jako prawo do życia rodzinnego, na które składają się różnego 
rodzaju więzi ${ }^{3}$. Sąd Najwyższy podkreślił jednak, że aby uznać więzi rodzinne za dobro osobiste, musi dojść do szczególnej sytuacji ich definitywnej utraty, której przyczyną jest śmierć osoby bliskiej będąca skutkiem działań osób trzecich. Przytoczona argumentacja SN poparta orzecznictwem jest prawidłowa, jednak niepełna. Sąd Najwyższy podaje jedynie jeden przypadek, jakim jest śmierć albo stan wegetatywny osoby bliskiej, która uzasadnia ochronę więzi rodzinnych jako dobra osobistego. Nawiązując do procedowanego stanu faktycznego, należy odróżnić sytuacje ochrony więzi rodzinnych w przypadku śmierci, od ochrony tych więzi w relacjach między osobami żyjącymi.

Kolejno, nie można uznać za słuszne twierdzenia, w którym SN uznaje, że za szczególnym charakterem zerwania więzi w wyniku śmierci czy zaistnienia stanu wegetatywnego przemawia fakt, iż ,po pierwsze, naruszenie więzi jest spowodowane przez czynniki (podmioty) zewnętrzne, a nie przez żaden z podmiotów relacji rodzinnych; po drugie, relacje pomiędzy naruszycielem dobra osobistego a poszkodowanym nie są w żaden sposób regulowane normami prawa rodzinnego". Z pewnością SN chciał w ten sposób wyjaśnić zasadność odmowy ochrony dobru osobistemu wywiedzionemu przez powoda. Uzasadnienie, jak powyżej, jest jednak chybione. Przesłanki te nie widnieją expressis verbis w treści art. 448 k.c., próżno również szukać ich uzasadnienia w piśmiennictwie. Przepis art. 448 k.c. daje możliwość dochodzenia swoich roszczeń przez wszystkie osoby fizyczne pokrzywdzone w wyniku naruszenia ich dóbr osobistych zawinionym działaniem ${ }^{4}$. Judykatura wskazuje na możliwość przyznania ochrony, a tym samym domagania się zadośćuczynienia, na podstawie art. 23 w zw. z art. 448 k.c. za krzywdę będącą skutkiem śmierci osoby najbliższej. Nie warunkuje jednak, aby możliwość taka istniała ze względu na zerwanie więzi przez podmiot niebędący członkiem rodziny oraz gdy relacja między sprawcą naruszenia a poszkodowanym nie podlega w żaden sposób przepisom prawa rodzinnego. Relewantne jest natomiast, aby doszło do całkowitego zerwania więzi rodzinnych, co ma miejsce w wyniku śmierci będącej skutkiem zawinionego działania osoby trzeciej, a w związku z tym poczucia krzywdy członków rodziny emocjonalnie związanych ze zmarłym ${ }^{5}$.

3 Tak na przykład wyrok Sądu Apelacyjnego w Warszawie z dnia 10 maja 2018 r. V ACa 1305/17, LEX nr 2504694; oraz z dnia 30 sierpnia 2017 r., VI ACa 646/16, LEX nr 2432008 (naruszenie dobra osobistego w postaci prawa do życia rodzinnego); wyrok Sądu Apelacyjnego w Warszawie z dnia 18 kwietnia 2018 r., V ACa 1195/17, LEX nr 2501256 (poczucie więzi rodzinnych między bliskimi jako dobro osobiste podlegające ochronie); wyrok Sądu Apelacyjnego w Warszawie z dnia 7 grudnia 2017 r., V ACa 200/17, LEX nr 2436622 (prawo do więzi rodzinnych z najbliższymi jako dobro osobiste); por. także obszerne orzecznictwo przytoczone w przedmiotowym wyroku SN.

${ }^{4}$ K. Osajda, Komentarz do art. 448, [w:] Kodeks cywilny. Komentarz, red. K. Osajda, Beck Online Komentarze 2019, nb 12.

5 Zob. wyrok Sądu Apelacyjnego w Warszawie z dnia 25 października 2018 r., V ACa 1463/17, LEX nr 2613626; wyrok Sądu Apelacyjnego w Łodzi z dnia 12 października 2018 r., I ACa 1616/17, LEX nr 2595388; wyrok Sądu Apelacyjnego w Gdańsku z dnia 14 grudnia 2007 r., I ACa 1137/07, LEX nr 466366. 
Wydaje się, że rozumienie nieostrego sformułowania, jakim jest „osoba trzecia”, w wypadku żądania zadośćuczynienia jak wyżej powinno oznaczać każdą osobę, która w sposób zawiniony dokonuje naruszenia dobra osobistego, bez względu na charakter relacji łączących ją z podmiotem żądającym ochrony. Przeciwna konstatacja SN prowadziłaby do nieuzasadnionego odmówienia ochrony określonej grupie pokrzywdzonych w wyniku naruszenia dóbr osobistych. Doszłoby bowiem do sytuacji, w której gdy jeden z podmiotów relacji rodzinnej (rodzic) pozbawi życia drugiego członka tej relacji, inny podmiot relacji rodzinnej (przykładowo dziecko), którego silna więź emocjonalna z członkiem najbliższej rodziny została definitywnie zerwana, nie mógłby dochodzić zadośćuczynienia na podstawie art. $24 \mathrm{w}$ zw. z art. 448 k.c. od podmiotu relacji rodzinnej, który jest jednocześnie naruszycielem.

Dodać trzeba, że zarówno orzecznictwo, jak i poglądy doktryny wskazują na możliwość dochodzenia zadośćuczynienia będącego rekompensatą ujemnych przeżyć psychicznych, jakie wiążą się ze śmiercią osoby najbliższej6. Kontrowersje zaistniałe w orzecznictwie, a dotyczące stosowania art. 448 k.c. oraz 446 $\S 4$ k.c., które przytoczył SN na kanwie wyroku, nie mają w przedmiotowym stanie faktycznym waloru przydatności. Dotyczą one bowiem przesłanek realizacji roszczenia o zadośćuczynienie ${ }^{7} \mathrm{w}$ związku ze śmiercią najbliższego członka rodziny lub doznania przez niego trwałego i ciężkiego uszczerbku na zdrowiu. Nie odnoszą się jednak w żaden sposób do problemu stosowania art. 23 w zw. $\mathrm{z}$ art. 448 k.c. dla ochrony więzi rodzinnych, rozumianych jako prawo do życia w rodzinie między podmiotami żyjącymi.

Należy zgodzić się z opinią SN, że fakt uznania więzi rodzinnej za dobro osobiste w wyjątkowej sytuacji, jaką jest na przykład śmierć członka najbliższej rodziny, nie oznacza zastosowania art. $24 \mathrm{w}$ zw. z art. 448 do każdego przypadku zerwania więzi rodzinnej. Nie można jednak uznać a priori, że wymienione przypadki są jedynymi, które uzasadniają ochronę więzi rodzinnych, jako dobra osobistego na podstawie wskazanych przepisów.

\subsection{OCHRONA W PRZYPADKU ŚMIERCI \\ ORAZ W RELACJI MIĘDZY OSOBAMI ŻYJĄCYMI}

Wobec tego celowe jest odróżnienie dwóch przypadków, które mają podstawowe znaczenie dla przyznania ochrony na podstawie art. $23 \mathrm{w} \mathrm{zw} . \mathrm{z}$ art. 448 k.c. Pierwszym z nich jest domaganie się ochrony dobra osobistego, które określić

${ }^{6}$ K. Osajda, Komentarz do art. 448..., nb 14.

7 Por. wyrok Sądu Najwyższego z dnia 16 kwietnia 2014 r., V CSK 320/13, LEX nr 1463645; wyrok Sądu Apelacyjnego w Łodzi z dnia 7 marca 2014 r., I ACa 1187/13, LEX nr 1454547; wyrok Sądu Apelacyjnego w Poznaniu z dnia 4 września 2013 r., I ACa 583/13, LEX nr 1375826; wyrok Sądu Apelacyjnego w Szczecinie z dnia 8 maja 2013 r., I ACa 188/13, LEX nr 1378849; wyrok Sądu Apelacyjnego w Poznaniu z dnia 23 stycznia 2013 r., I ACa 1134/12, LEX nr 1264390. 
można jako szczególną więź emocjonalną z członkiem rodziny, której definitywne zerwanie na skutek śmierci czy stanu wegetatywnego, powoduje krzywdę. W tej sytuacji istotne znaczenie ma przede wszystkim fakt całkowitego zerwania więzi, będącego skutkiem zdarzenia nagłego, nieprzewidzianego ${ }^{8}$. Są to wszystkie przypadki, w których zerwanie więzi nastąpiło na skutek śmierci albo innego ciężkiego i trwałego uszczerbku na zdrowiu osoby najbliższej. Dla przyznania zadośćuczynienia na podstawie art. $24 \mathrm{w}$ zw. $\mathrm{z}$ art. 448 k.c. nie wydaje się natomiast istotne, czy skutek wywołała osoba trzecia, będąca przykładowo nieznajomym sprawcą wypadku drogowego czy też innym najbliższym członkiem rodziny (na przykład jednym $z$ rodziców).

Drugim z zasygnalizowanych przypadków jest żądanie ochrony dobra osobistego, rozumianego jako poczucie istnienia więzi rodzinnej między pozostającymi przy życiu członkami rodziny, gdy do całkowitego zerwania dochodzi z woli jednego z członków relacji rodzinnej. W takim stanie faktycznym orzekał Sąd Apelacyjny w Krakowie w wyroku z dnia 22 listopada 2017 roku$^{9}$, słusznie podnosząc, że

ochrona dobra osobistego, jakim jest więź rodzinna, nie może być odnoszona do zerwania tej więzi z woli jednego z jej podmiotów (np. jednego z małżonków), a jedynie do sytuacji, gdy więź ta rzeczywiście z woli jej podmiotów istnieje i ustaje na skutek działań osób trzecich, prowadzących do jej zerwania wbrew woli osób, które więź ta łączy.

Istotny pogląd $\mathrm{w}$ sprawie wyraził również sąd apelacyjny w wyroku z dnia 30 kwietnia 2015 roku, odmawiając ochrony prawnej dóbr osobistych w postaci prawa do rodziny. Uznał wówczas, że nie może ono mieć miejsca, gdy jeden z małżonków w sposób zawiniony doprowadza do rozpadu pożycia małżeńskiego. Sąd orzekł, że: ,naruszenie dobra osobistego w postaci prawa do rodziny może mieć miejsce w sytuacji dobrze funkcjonującej rodziny i dokonania naruszenia przez osobę trzecią"10.

Odnosząc się do pierwszej z przedstawionych sytuacji, skutek w postaci śmierci czy stanu wegetatywnego jest nieodwracalny. Zerwanie relacji jest definitywne, dzieje się to bez woli podmiotów relacji rodzinnej, jest wynikiem bezprawnego działania na gruncie prawa cywilnego, rozumianego jako czyn niezgodny z przepisami ustawy lub zasadami współżycia społecznego. Konsekwencją takiego skutku jest też niejednokrotnie zwiększenie odpowiedzialności karnej za popełnienie czynu zabronionego w rozumieniu kodeksu karnego ${ }^{11}$. W drugim przypadku działanie

8 W takim stanie faktycznym orzekał między innymi Sąd Apelacyjny w Warszawie w wyroku z dnia 26 października 2017 r., I ACa 1239/16, LEX nr 2412781.

9 Wyrok Sądu Apelacyjnego w Krakowie z dnia 22 listopada 2017 r., I ACa 714/17, LEX nr 2464946.

10 Wyrok Sądu Apelacyjnego w Katowicach z dnia 30 kwietnia 2015 r., I ACa 60/15, LEX nr 1740651.

11 Por. ustawa z dnia 6 czerwca 1997 roku - Kodeks karny, tekst jedn. Dz.U. z 2019 r. poz. 1950 ze zm., Przestępstwa przeciwko życiu i zdrowiu, art. 148-162. 
podmiotu relacji rodzinnej, którego wolą jest zerwanie więzi rodzinnych, choć zasługuje nierzadko na negatywną ocenę $\mathrm{z}$ punktu widzenia zasad współżycia społecznego, jest jednak wykonywaniem własnego prawa podmiotowego, jakim jest możliwość decydowania o swojej sytuacji osobistej. Ochrony przed skutkami tego działania (na przykład w postaci zdrady małżeńskiej), o ile nie wiążą się z rzeczywistym naruszeniem dobra osobistego (zdrowia, czci, dobrego imienia), nie można domagać się na gruncie przepisów o ochronie dóbr osobistych. Jednak jak słusznie podkreśla A. Tokarz, domaganie się ochrony dobra osobistego w postaci zdrowia czy życia na podstawie art. $23 \mathrm{w}$ zw. z art. 448 k.c. wydaje się znacznie utrudnione ze względu na konieczność udowodnienia zwykłego związku przyczynowego między zdradą, a skutkiem w postaci uszczerbku na zdrowiu ${ }^{12}$.

\subsection{OCHRONA DÓBR OSOBISTYCH W WYNIKU NARUSZENIA OBOWIĄZKÓW MAŁŻEŃSKICH}

Celnie wskazuje się w orzeczeniu, że nie jest możliwa ochrona wzajemnych więzi między małżonkami (pokrewieństwa lub powinowactwa) przez instrumenty prawa rodzinnego, jeżeli prawo to instrumentów takich nie przewiduje. Bezsporne jest, że k.r.o. w obecnym kształcie nie daje możliwości domagania się zadośćuczynienia za krzywdę spowodowaną zerwaniem więzi rodzinnych na skutek rozpadu małżeństwa z winy jednego z małżonków. Sąd Najwyższy nie wyjaśnił jednak, z jakiego powodu zachowanie pozwanych mogło odnieść skutki jedynie w sferze prawa rodzinnego. Trzeba zatem wyjaśnić, że w stanie faktycznym doszło do naruszenia obowiązków małżeńskich uregulowanych w art. 23 k.r.o., których naruszenie, jeżeli nie łączy się jednocześnie $\mathrm{z}$ wypełnieniem przesłanek uznania konkretnego zachowania za naruszenie dóbr osobistych na gruncie art. 24 k.c., wywołuje skutki jedynie przewidziane przez przepisy prawa rodzinnego.

Zawarcie związku małżeńskiego wiąże się z powstaniem stosunku rodzinnoprawnego, który jest rodzajem stosunku cywilnoprawnego. Jego treścią są natomiast prawa i obowiązki małżonków ${ }^{13}$. Jednym z obowiązków, jakie nakłada art. 23 k.c., jest lojalność małżeńska, w którą wpisuje się między innymi wierność ${ }^{14}$. Podkreśla się, że przepisy dotyczące praw i obowiązków małżonków, mają

12 A. Tokarz, Zdrada matżeńska. Zadośćuczynienie za zerwanie więzi rodzinnych, „Przegląd Sądowy" 2011, nr 4, s. 107.

${ }_{13}$ Zob. więcej na ten temat M. Goettel, Koncepcja podstawowych praw i obowiązów matżonków w kodeksie rodzinnym i opiekuńczym, [w:] Matżeństwo i rodzina w prawie kanonicznym, polskim i międzynarodowym. Księga pamiątkowa dedykowana ks. prof. Ryszardowi Sztychmilerowi, red. T. Płoski, Olsztyn 2008, s. 343; T. Smyczyński, [w:] System Prawa Prywatnego, t. 11. Prawo rodzinne i opiekuńcze, red. T. Smyczyński, J. Gajda, Warszawa 2014, nb 3, s. 215; M. Jadczak-Żebrowska, Prawa i obowiąki matżonków, Warszawa 2017, s. 23-26.

14 Obowiązek wierności w ujęciu wąskim oznacza nakaz powstrzymania się od kontaktów płciowych z innymi niż współmałżonek osobami. Tak między innymi S. Szer, Prawo rodzinne, Warszawa 1966, s. 82; R. Krajewski, Prawa i obowiqzki seksualne matżonków. Studium prawne 
istotne znaczenie z punktu widzenia postępowania rozwodowego. Niewypełnianie obowiązków małżeńskich rzutuje między innymi na możliwość orzeczenia rozwodu czy zakres obowiązków alimentacyjnych ${ }^{15}$. Treść przepisów k.r.o. traktujących o prawach i obowiązkach małżonków ma dwa podstawowe znaczenia. Po pierwsze, ukazuje funkcje, jakie pełni małżeństwo ${ }^{16}$. Po drugie zaś, wyraża aksjologię przepisu art. 18 konstytucji ${ }^{17}$, który za cel stawia sobie, jak to ujął Z. Jancewicz, ochronę tej „najmniejszej i podstawowej wspólnoty” ${ }^{18}$, którą tworzy się, zakładając rodzinę ${ }^{19}$. Uregulowanie dotyczące praw i obowiązków małżonków odzwierciedla również akceptowane społecznie normy obyczajowe, które wyrażają się chociażby w wykluczeniu ingerencji osób trzecich w intymną relację małżeńską ${ }^{20}$.

Prawa i obowiązki małżonków określone w k.r.o. mają charakter cywilnych praw podmiotowych ${ }^{21}$, jednak ze względu na szczególny prawnorodzinny charakter wykazują wiele odmienności ${ }^{22}$. Wskazuje się, analizując relację małżeńską z punktu widzenia prawa cywilnego, że jest to więź obligacyjna łącząca dwa podmioty, której treść, czyli prawa i obowiązki, są takie same dla obu podmiotów ${ }^{23}$. Nie można jednak prawom i obowiązkom małżeńskim przyznać charakteru ekwiwalentności. Z jednej strony mamy bowiem do czynienia z sytuacją, w której obowiązek określonego zachowania się spoczywa tylko na jednej stronie (pomoc w czasie choroby), z drugiej natomiast fakt, że jeden z małżonków nie wypełnia obowiązku, nie stanowi sam przez się o możliwości wstrzymania się z wykonaniem obowiązku przez drugiego małżonka ${ }^{24}$.

Postuluje się, że w sferę życia prywatnego człowieka, która jest jego dobrem osobistym, wpisują się między innymi relacje małżeńskie ${ }^{25}$. Nie oznacza to jednak

nad norma i patologia zachowań, Warszawa 2009, s. 308. Z powinności tej wynika zakaz zdrady małżeńskiej jak trafnie ujął to SN w orzeczeniu z 8 maja 1951 r., C 184/51, LEX nr 117064.

15 K. Osajda, Komentarz do art. 23 k.r.o., [w:] Kodeks rodzinny i opiekuńczy. Komentarz, red. K. Osajda, Beck Online Komentarze 2019, nb VIII.

16 Zob. M. Goettel, op. cit., s. 344.

17 Konstytucja Rzeczypospolitej Polskiej z dnia 2 kwietnia 1997 roku, Dz.U. z 1997 r. Nr 78 , poz. 483, art. 18. Podkreśla się przepisy dotyczące praw i obowiązków małżonków stanowią wyraz obowiązującego modelu prawnego małżeństwa; zob. M. Sychowicz, Komentarz do art. 23 k.r.o., [w:] Kodeks rodzinny i opiekuńczy. Komentarz, red. K. Piasecki, Warszawa 2011, nb 2-3; M. Andrzejewski, Prawo rodzinne i opiekuńcze, Warszawa 2014, s. 60.

18 Z. Jancewicz, Obowiązek wzajemnej pomocy matżonków z art. 23 Kodeksu rodzinnego i opiekuńczego, „Roczniki Nauk Prawnych” 25, 2015, nr 4, s. 8.

19 Jak słusznie wskazał M. Goettel, art. 23-30 k.r.o. określa te prawa i obowiązki małżeńskie, które są nierozerwalnie związane z podstawowymi funkcjami, jakie pełni związek małżeński. Zob. więcej na ten temat M. Goettel, op. cit., s. 344.

20 Tak ujął to SN w wyroku z dnia 29 czerwca 2000 r., V CKN 323/00, LEX nr 52485.

21 Zob. J. Ignatowicz, M. Nazar, Prawo rodzinne, Warszawa 2016, s. 220.

22 K. Osajda, Komentarz do art. 23..., nb 122.

23 Ibidem, nb 124.

24 Ibidem, nb 124-125; por. art. 487 § 2 oraz 488 § 2 k.c.

25 Zob. między innymi M. Goettel, op. cit., s. 353; M. Sychowicz, op. cit., nb 8. 
możliwości domagania się ochrony tych praw przez zakaz zbliżania się do współmałżonka czy nawiązywania kontaktów, które mogłyby naruszyć relację małżeńską. Relacja małżeńska, będąc elementem sfery życia prywatnego człowieka, jest jego osobistym dobrem rozumianym w ten sposób, iż jest on władny chronić swoją prywatność i kształtować ją w dowolny sposób. Wskazać jednak należy, że przepisy regulujące prawa i obowiązki małżeńskie mają charakter norm ius cogens, co skutkuje tym, że nie można sporządzić skutecznej umowy dotyczącej wyłączenia ich obowiązywania ${ }^{26}$. Niewykluczone jest jednak faktyczne doprecyzowanie tych praw i obowiązków, co stanowi kwestię indywidualną i zależy od woli samych małżonków ${ }^{27}$. Trafnie opisuje to S. Grzybowski, wskazując, że

nie można jednak odmówić znaczenia porozumienia się małżonków co do ich wspólnego pożycia i wzajemnej wierności, i to tym bardziej, że nałożony przez k.r.o. obowiązek nie jest wymuszalny w drodze postępowania sądowego. [...] Mimo to naruszenie owego obowiązku, nawet zgodnie z zawartym przez małżonków porozumieniem, może uzasadniać orzeczenie rozwodu, ale z tej dopiero przyczyny, że nastąpił trwały i zupełny rozkład pożycia ${ }^{28}$.

Wskazuje on tym samym, że nie można egzekwować obowiązku wierności. Odnosząc to do stanu faktycznego, nad którym procedował SN, przyznanie ochrony poczuciu istnienia więzi rodzinnych z żoną i dziećmi, które zostało naruszone przez zdradę żony, byłoby niczym innym jak próbą wymuszenia obowiązku małżeńskiego, jakim jest wierność.

Słusznie wskazuje się, że nie wszystkie prawa i obowiązki nałożone na małżonków w k.r.o. mogą tworzyć przedmiot roszczeń i w związku z tym być dochodzone w postępowaniu sądowym. Nie należy do nich z pewnością obowiązek wierności ${ }^{29}$. Niemożność stosowania przymusu co do wykonania obowiązków małżeńskich podkreślano już na kanwie stosowania nieobowiązującego art. 14 dekretu Prawo małżeńskie ${ }^{30}$. Podaje się, że A. Wolter wskazywał, iż przymus taki byłby niemożliwy, lecz nie ze względu na brak normy prawnej, lecz dlatego że brakuje możliwości jego wykonania i jest sprzeczny z zasadą wolności osobistej $^{31}$. W najnowszym piśmiennictwie podkreśla się, że naruszenie przepisów dotyczących praw i obowiązków małżonków nie wiąże się z sankcją cywilną. Konsekwencje zachowania niezgodnego z wspomnianymi przepisami odnoszą jednak

26 J. Gajda, Komentarz do art. 23 k.r.o., [w] Kodeks rodzinny i opiekuńczy. Komentarz, red. K. Pietrzykowski, 2018, nb 1; zob. także S. Grzybowski, Prawo rodzinne. Zarys wykładu, Warszawa 1980, s. 70; K. Osajda, Komentarz do art. 23..., nb 131.

27 K. Osajda, Komentarz do art. 23..., nb 132.

28 S. Grzybowski, op. cit., s. 70.

29 K. Osajda, Komentarz do art. 23..., nb 140.

30 Dekret z dnia 25 września 1945 roku Prawo małżeńskie, Dz.U. z 1945 r. Nr 48, poz. 270 (dalej: PrMałżD).

31 K. Osajda, Komentarz do art. 23..., nb 142. 
skutki, rzutując między innymi na treść orzeczenia w postępowaniu rozwodowym czy spadkowym. Sankcje te nazywane są pośrednimi lub oddalonymi czasowo ${ }^{32}$.

Jak trafnie wskazał $\mathrm{SN}$, w nieobowiązującym już stanie prawnym ${ }^{33}$ istniała możliwość przyznania zarówno odszkodowania, jak i zadośćuczynienia w wyroku orzekającym rozwód. Roszczenia te przysługiwały małżonkowi niewinnemu rozpadowi pożycia $\mathrm{w}$ związku z czynami, które stały się podstawą orzeczenia rozwodu, a więc naruszeniem obowiązków małżeńskich. W obecnie obowiązującym k.r.o. ustawodawca nie przewidział takiej możliwości, co nie może skutkować stosowaniem przepisu art. 23 k.r.o. in fraudem legis odnośnie do formułowania roszczenia w związku z naruszeniem dóbr osobistych i dochodzeniem na tej podstawie zadośćuczynienia $\mathrm{z}$ art. 488 k.c. Przepis art. 23 k.r.o. ma na celu ochronę rodziny jako podstawowej komórki społecznej, stanowi postulat, który statuuje nie tylko o równości praw i obowiązków małżonków ${ }^{34}$, lecz także o woli ustawodawcy utrzymania przez ich wypełnianie zgodnego małżeństwa. O celu, jaki przyświecał ustawodawcy, świadczy również art. $3 \S 3$ k.r.o., obligujący kierownika urzędu stanu cywilnego do pouczenia o przepisach regulujących prawa i obowiązki małżonków. Pożądane jest bowiem, aby nupturienci zamierzający zawrzeć związek małżeński byli świadomi przepisów regulujących stosunki prawnorodzinne. To, w jaki sposób prawa i obowiązki są faktycznie realizowane, należy do sfery życia prywatnego, które jest dobrem osobistym każdego człowieka. W związku z tym wydaje się, że w obecnym stanie prawnym przytoczony wcześniej przepis art. 29 nieobowiązującego już dekretu byłby niezgodny zarówno z art. 31 ust. 1, jak i art. 47 Konstytucji RP.

\section{PODSUMOWANIE}

Stanowisko Sądu Najwyższego należy ocenić w danej sprawie aprobująco, jednak argumentacja, jaką poczynił sąd, jest niewątpliwie wybiórcza i mało klarowna. Zaznaczyć raz jeszcze trzeba, że z żadnej normy prawnej nie wynika wymóg, aby relacja między podmiotem żądającym ochrony na podstawie art. 23 w związku z art. 488 k.c. a naruszycielem nie była regulowana w żaden sposób przepisami prawa rodzinnego. Natomiast za uznaniem śmierci osoby najbliższej za szczególny wypadek uzasadniający ochronę przesądza nieodwracalny skutek oraz istnienie szczególnej więzi emocjonalnej między nieżyjącym członkiem najbliższej

32 Ibidem, nb 141. Por. J. Ignatowicz, M. Nazar, op. cit., s. 225; S. Grzybowski, op. cit., s. 78. $\mathrm{Na}$ temat sankcji pośrednich prawa spadkowego zob. W. Borysiak, Komentarz do art. 23 k.r.o., [w:] Komentarz KRO, red. W. Borysiak, J. Wierciński, nb 65.

33 Por. PrMałżD, art. 29.

${ }^{34}$ K. Osajda, Komentarz do art. 23..., nb 14. 
rodziny a osobą, która żąda zadośćuczynienia. Abstrahując od powyższego, SN nie pochylił się nad wyjaśnieniem, z jakiego powodu przepisy o ochronie dóbr osobistych nie mają zastosowania w przypadku zdrady małżeńskiej. Wspomniał jedynie, że taka możliwość istniała zgodnie z nieobowiązującym już dekretem z 1945 roku. Nie wythumaczył jednak, dlaczego na tle aktualnego orzecznictwa skutki naruszenia niektórych obowiązków małżeńskich nie stwarzają roszczeń cywilnoprawnych, lecz jedynie konsekwencje w postaci tak zwanych sankcji oddalonych w czasie. $\mathrm{W}$ przedmiocie problematyki więzi rodzinnych jako dobra osobistego orzeczeniu, choć trafnemu w swej tezie, należy zarzucić nieelastyczność. Widoczna jest chęć ograniczenia przypadków ochrony więzi rodzinnych na podstawie art. $23 \mathrm{w} z \mathrm{zW}$. $\mathrm{z}$ art. 488 k.c. wyłącznie do sytuacji, w których doszło do śmierci czy stanu wegetatywnego osoby najbliższej, podczas gdy judykatura wskazuje na dynamiczny rozwój orzecznictwa w przedmiocie dóbr osobistych ${ }^{35}$. Trafne wydaje się zatem, aby główne znaczenie z punktu widzenia naruszenia dóbr osobistych miało występowanie w partykularnym stanie faktycznym przesłanek warunkujących ochronę aniżeli odwoływanie się do utrwalonych linii orzeczniczych.

\title{
PROTECTION OF FAMILY AND LEGAL TIES WITH REGARD TO THE PROTECTION OF PERSONAL RIGHTS. COMPENSATION FOR NON-FULFILLMENT OF MARITAL OBLIGATIONS. THE GLOSS TO THE JUDGMENT OF THE SUPREME COURT OF 11 DECEMBER 2018 (IV CNP 31/17)
}

\begin{abstract}
Summary
The issue of personal rights and their legal protection is constantly updated. The gloss to the judgment of the Supreme Court of 11 December 2018 indicates the issues of the development of jurisprudence regarding personal rights on the example of the so-called marital infidelity, in the case of which the provisions on the protection of personal rights do not apply to the protection of family ties between spouses. The author approves the judgment of the Supreme Court, extending his arguments and pointing to legal issues that may arise in connection with the interpretation of the judgment.
\end{abstract}

Keywords: family and legal ties, violation of marital obligations, redress, compensation for harm, marital treason, marital fidelity

35 Sąd Najwyższy w uchwale siedmiu sędziów z 16 lipca 1993 r., I PZP 28/93, LEX nr 3943 , trafnie ujął, że ,pojęcie dóbr osobistych należy odnosić do określonego poziomu rozwoju technologicznego i cywilizacyjnego, przyjętych w społeczeństwie zasad moralnych i prawnych, istniejącego rodzaju stosunków społecznych, gospodarczych, nawet politycznych”. 


\section{BIBLIOGRAFIA}

\section{MONOGRAFIE}

Andrzejewski M., Prawo rodzinne i opiekuńcze, Warszawa 2014.

Grzybowski S., Prawo rodzinne. Zarys wyktadu, Warszawa 1980.

Ignatowicz J., Nazar M., Prawo rodzinne, Warszawa 2016.

Jadczak-Żebrowska M., Prawa i obowiazki małżonków, Warszawa 2017.

Krajewski R., Prawa i obowiązi seksualne matżonków. Studium prawne nad norma i patologia zachowań, Warszawa 2009.

Smyczyński T., System Prawa Prywatnego, t. 11. Prawo rodzinne i opiekuńcze, red. J. Gajda, Warszawa 2014.

Szer S., Prawo rodzinne, Warszawa 1966.

\section{ARTYKUŁY}

Goettel M., Koncepcja podstawowych praw i obowiazków malżonków w kodeksie rodzinnym i opiekuńczym, [w:] Malżeństwo i rodzina w prawie kanonicznym, polskim i międzynarodowym. Księga pamiatkowa dedykowana ks. prof. Ryszardowi Sztychmilerowi, red. T. Płoski, Olsztyn 2008.

Jancewicz Z., Obowiązek wzajemnej pomocy matżonków z art. 23 Kodeksu rodzinnego i opiekuńczego, „Roczniki Nauk Prawnych” 25, 2015, nr 4.

Tokarz A., Zdrada matżeńska. Zadośćuczynienie za zerwanie więzi rodzinnych, „Przegląd Sądowy” $2011, \mathrm{nr} 4$.

\section{KOMENTARZE}

Osajda K., Komentarz do art. 23 k.r.o., [w:] Kodeks rodzinny i opiekuńczy. Komentarz, red. K. Osajda, Beck Online Komentarze 2019.

Osajda K., Komentarz do art. 448, [w:], Kodeks cywilny. Komentarz, red. K. Osajda, Beck Online Komentarze 2019.

Sychowicz M., Komentarz do art. 23 k.r.o., [w:] Kodeks rodzinny i opiekuńczy. Komentarz, red. K. Piasecki, Warszawa 2011.

\section{AKTY PRAWNE}

Dekret z dnia 25 września 1945 roku Prawo małżeńskie, Dz.U. z 1945 r. Nr 48, poz. 270.

Konstytucja Rzeczypospolitej Polskiej z dnia 2 kwietnia 1997 roku, Dz.U. z 1997 r. Nr 78, poz. 483. Ustawa z dnia 23 kwietnia 1964 roku — Kodeks cywilny, tekst jedn. Dz.U. z 2019 r. poz. 1145 ze zm.

Ustawa z dnia 6 czerwca 1997 roku — Kodeks karny, tekst jedn. Dz.U. z 2019 r. poz. 1950 ze zm.

\section{ORZECZNICTWO}

Uchwała siedmiu sędziów Sądu Najwyższego z dnia 16 lipca 1993 r., I PZP 28/93, LEX nr 3943. Wyrok Sądu Najwyższego z dnia 8 maja 1951 r., C 184/51, LEX nr 117064.

Wyrok Sądu Najwyższego z dnia 29 czerwca 2000 r., V CKN 323/00, LEX nr 52485.

Wyrok Sądu Najwyższego z dnia 16 kwietnia 2014 r., V CSK 320/13, LEX nr 1463645.

Wyrok Sądu Najwyższego z dnia 11 grudnia 2018 r., IV CNP 31/17, LEX nr 2621125. 
Wyrok Sądu Apelacyjnego w Gdańsku z dnia 14 grudnia 2007 r., I ACa 1137/07, LEX nr 466366. Wyrok Sądu Apelacyjnego w Katowicach z dnia 30 kwietnia 2015 r., I ACa 60/15, LEX nr 1740651. Wyrok Sądu Apelacyjnego w Krakowie z dnia 22 listopada 2017 r., I ACa 714/17, LEX nr 2464946. Wyrok Sądu Apelacyjnego w Lodzi z dnia 7 marca 2014 r., I ACa 1187/13, LEX nr 1454547. Wyrok Sądu Apelacyjnego w Łodzi z dnia 12 października 2018 r., I ACa 1616/17, LEX nr 2595388. Wyrok Sądu Apelacyjnego w Poznaniu z dnia 23 stycznia 2013 r., I ACa 1134/12, LEX nr 1264390. Wyrok Sądu Apelacyjnego w Poznaniu z dnia 4 września 2013 r., I ACa 583/13, LEX nr 1375826. Wyrok Sądu Apelacyjnego w Warszawie z dnia 30 sierpnia 2017 r., VI ACa 646/16, LEX nr 2432008. Wyrok Sądu Apelacyjnego w Warszawie z dnia 26 października 2017 r., I ACa 1239/16, LEX nr 2412781.

Wyrok Sądu Apelacyjnego w Warszawie z dnia 7 grudnia 2017 r., V ACa 200/17, LEX nr 2436622. Wyrok Sądu Apelacyjnego w Warszawie z dnia 18 kwietnia 2018 r., V ACa 1195/17, LEX nr 2501256.

Wyrok Sądu Apelacyjnego w Warszawie z dnia 10 maja 2018 r., V ACa 1305/17, LEX nr 2504694. Wyrok Sądu Apelacyjnego w Warszawie z dnia 25 października 2018 r., V ACa 1463/17, LEX nr 2613626.

Wyrok Sądu Apelacyjnego w Szczecinie z dnia 8 maja 2013 r., I ACa 188/13, LEX nr 1378849. 